\title{
Language and Archaeology
}

\author{
Willem J.H. Willems, Faculty of Archaeology, Leiden University, \\ PO Box 9515, 2300 RA, Leiden, The Netherlands \\ E-mail: W.J.H.Willems@arch.leidenuniv.nl
}

\begin{abstract}
The increase in the number of publications per year is connected to a decrease in their geographical scope and hence in the number and diversity of the international references. The nature of communication is thus decidedly influenced by language communities and their size, and in Europe has given rise to distinct traditions. My personal feeling is that these have enriched our discipline immensely.
\end{abstract}

Resumen: El aumento en el número de publicaciones anuales está conectado con la disminución de su cubrimiento geográfico y, por lo tanto, con la cantidad y diversidad de las referencias internacionales. La naturaleza de la comunicación está entonces, indudablemente, influenciada por las comunidades linguísticas y sus dimensiones que han producido tradiciones distintas en Europa. Creo que estas tradiciones han enriquecido nuestra disciplinas inmensamente.

Résumé: L'augmentation du nombre de publications par année est liée à la diminution de la portée géographique et par conséquence du nombre et de la diversité des références internationales. La nature des communications est donc indubitablement influencée par les communautés linguistiques et leurs dimensions, ce qui a produit des traditions distinctes en Europe. Mon impression personnel est que cela à grandement enrichie notre discipline.

There are many emotions related to language. I find it regrettable that Latin didn't survive as the lingua franca in academia, but I personally have no problem with English as the new Latin. Apart from emotional approaches and political viewpoints, the role of language can also be investigated. There has, however, been very little research into the effect of language on practices in both academic research and heritage management in archaeology. Obviously, the English discourse is so dominant at the global level that it may seem to be the only one-especially to native speakers of English that often tend to have rather poorly developed language skills. 
For Europe, an interesting analysis was published by Evzen Neustupný (Neustupný 1998). In this publication he defines 'mainstream' and 'minority' research communities in Europe. The larger groups (German, English, French, Russian, and Spanish) he terms 'mainstream'. These are the communities that are big enough to have a full internal discourse on all relevant topics in the discipline, so there is no immediate need to refer to outside sources or to participate in other discourses. For his 'minority' communities that is not possible. Indeed, the Scandinavian, Dutch, or Czech 'minority' communities traditionally have a very outspoken international orientation.

The point is, however, that what happens inside a large community - with the exception of the English one-tends to remain there for lack of communication across the language border. A recent citation-analysis of references to academic and professional archaeological literature (Kristiansen 2001) indicates that this phenomenon is not decreasing, as one might expect in the age of globalization, but that it is actually increasing. Over the past decade or so, there is a clear increase in the geographical constraints on citation, even in the smaller research communities.

The causes for this may well have to do with the rapid growth of these communities in recent years. In many European countries this increase can be attributed to the enormous growth of archaeological heritage resource management as a result of the implementation of the Valletta Convention. The increase in the number of publications per year is connected to a decrease in their geographical scope and hence in the number and diversity of the international references.

The nature of communication is thus decidedly influenced by language communities and their size, and in Europe has given rise to distinct traditions. My personal feeling is that these have enriched our discipline immensely.

\section{Open Access}

This article is distributed under the terms of the Creative Commons Attribution Noncommercial License which permits any noncommercial use, distribution, and reproduction in any medium, provided the original author(s) and source are credited.

\section{References Cited}

Kristiansen, K.

2001. Borders of Ignorance: Research Communities and Language. In Quo Vadis Archaeologia? Whither European Archaeology in the 21st Century, edited by Z. Kobyliński, pp. 38-43. European Science Foundation/Polish Academy of Sciences, Warsaw. 
Neustupný, E.

1998. Mainstreams and Minorities in Archaeology. Archaeologia Polona 3536:13-23. 